\title{
Part 5
}

\section{Living the Life: Transitions and transformations, Life on campus}

\author{
Cecille DePass
}

Part 5 samples key aspects of being participants and actors in the UWI community. It begins with snapshots from: Glean Walker (egs., carnival in the late 1960s, a hall of residence and students' social and recreational activities); Subero, nee Lee's photos complement Glean Walker's first photographs. The tone shifts significantly with Dopwell, nee Commissiong's memories of past and present life on campus. Finally, artwork by Campbell, and poems by Robertson, nee Harrison, Dixon and Craig explore issues of identity and humanity.

"All men are caught in an inescapable network of mutuality, tied in a single garment of destiny. Whatever affects one directly affects all indirectly. I can never be what I ought to be until you are what you ought to be, and you can never be what you ought to be until I am what I ought to be". Martin Luther King, Jr. (Quote 4, Embracing Our Global Community. In: World Quotes, Living in Community. From Google).

"Each of us must rededicate ourselves to serving the common good. We are a community. Our individual fates are linked; our futures are intertwined; and if we act in that knowledge and in that spirit together, as the Bible says: 'We can move mountains'." Jimmy Carter. (Quote 2, Valuing Community. From Google).

The 1960s marked periods of major social, political and economic changes in the USA, the Caribbean and the UWI. Part 5 presents a series of visual images and some texts to illustrate the transitions and transformations which took place in the lives of some of us who lived either on campus or were day students. The 1960s were a pretty, heady time to be actively involved with the university. Photo Journals by Gillian Glean Walker and Terry/Teresa (Lee) Subero, as well as, a series of reflections (presented as poetry and artwork) by Ros Dopwell, Carol Campbell, Dorothy Robertson, Sandra Dixon and Christine Craig, all spotlight important aspects of our lives at the UWI.

This part of the book, includes selected photos submitted by Gillian Glean Walker of special events, daily campus life and a candid photo of Sir Philip Sherlock, as some of us remember him.

Part 5 concludes with:

- An extract from Ros Dopwell's letter to Gillian Glean Walker (2000);

- A piece of artwork by Carol Campbell; and,

- Poems by Dorothy Robertson, Sandra Dixon and Cristine Craig. 


\section{Revisiting the Past: A Photo Journal} Samples of Photos by and from Gillian Glean Walker's Archives

\section{Series 1: Snapshots of Carnival}

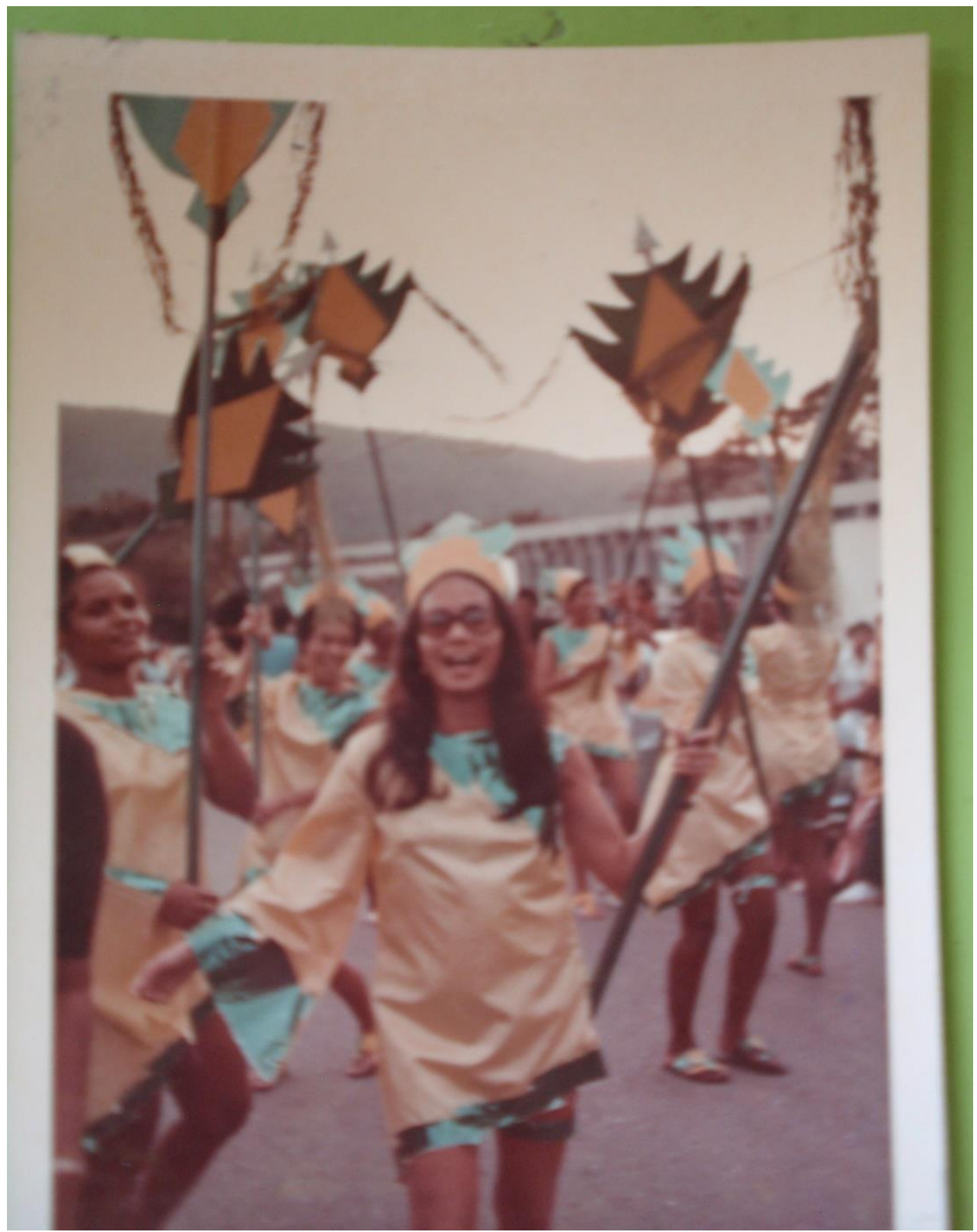

1969 Road March: "Mama dis is mass".

Cultural and Pedagogical Inquiry, Winter 2019, 11(1), pp. 105-136

ISSN 1916-3460 () 2019 University of Alberta

http://ejournals.library.ualberta.ca/index.php/cpi/index 


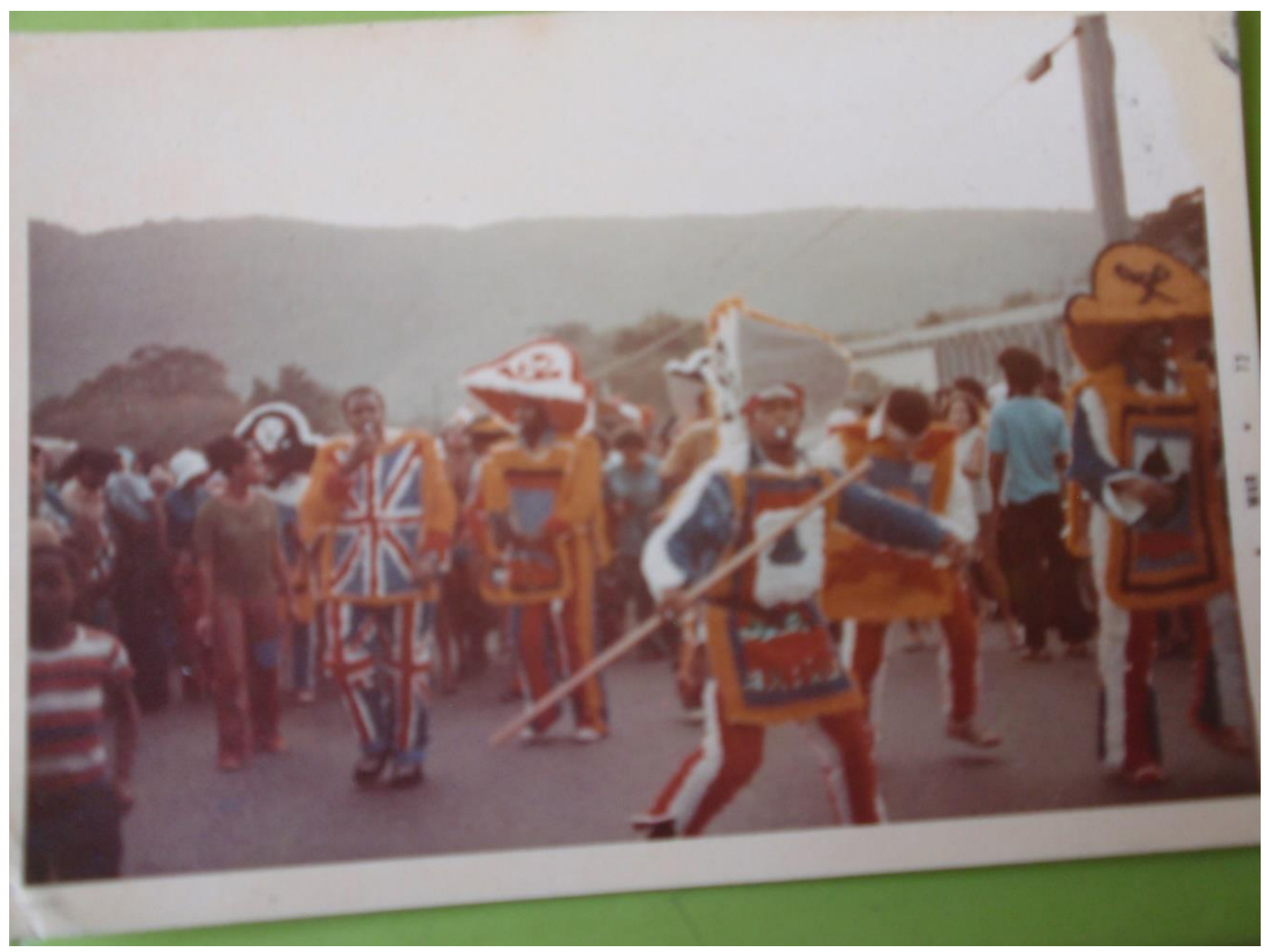

1969 Road March: "Mama dis is mass".

Cultural and Pedagogical Inquiry, Winter 2019, 11(1), pp. 105-136 


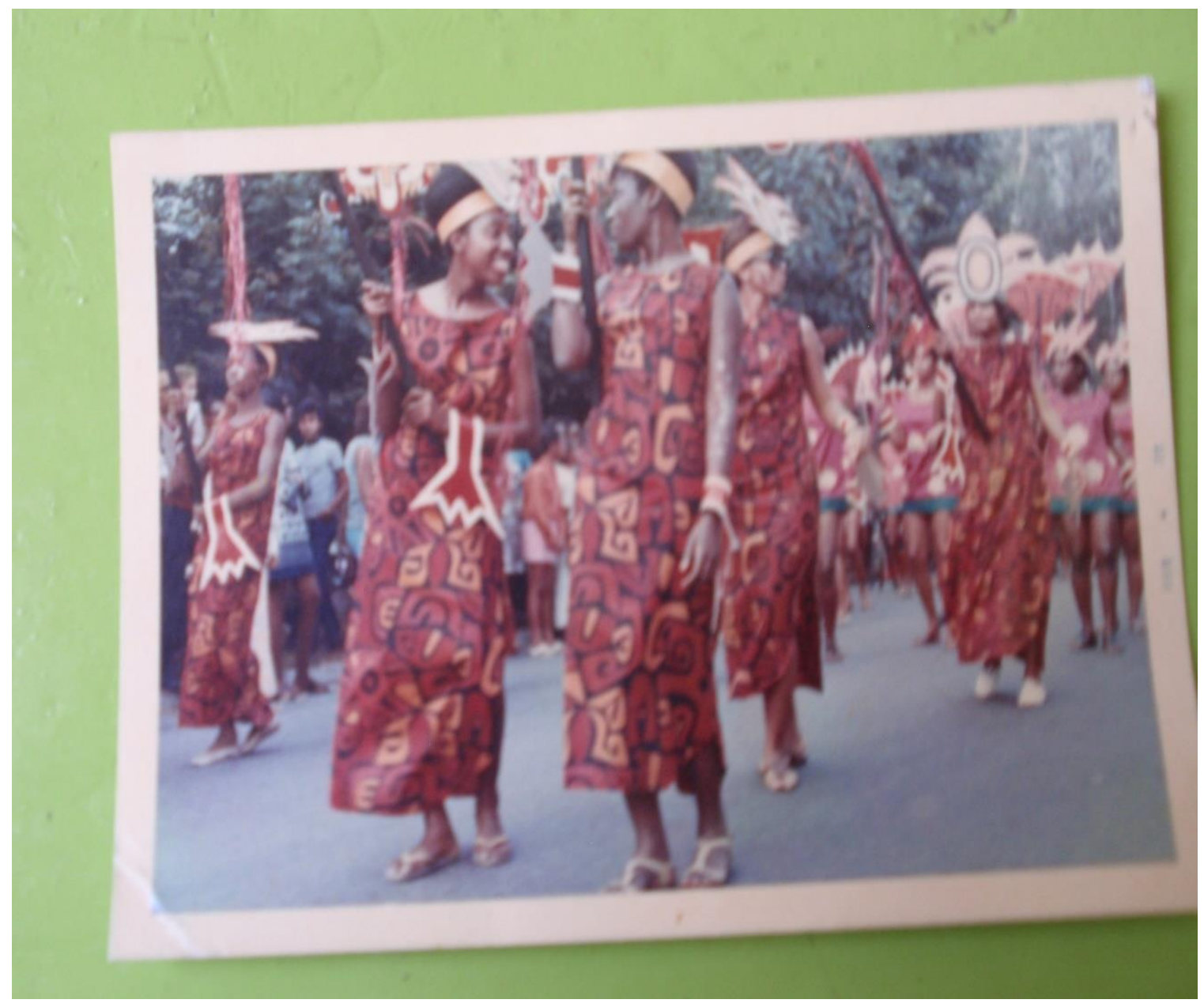

1969 Road March: "Mama dis is mass".

Cultural and Pedagogical Inquiry, Winter 2019, 11(1), pp. 105-136 
Series 2: Snapshots of Carnival Queen Competition, 1969

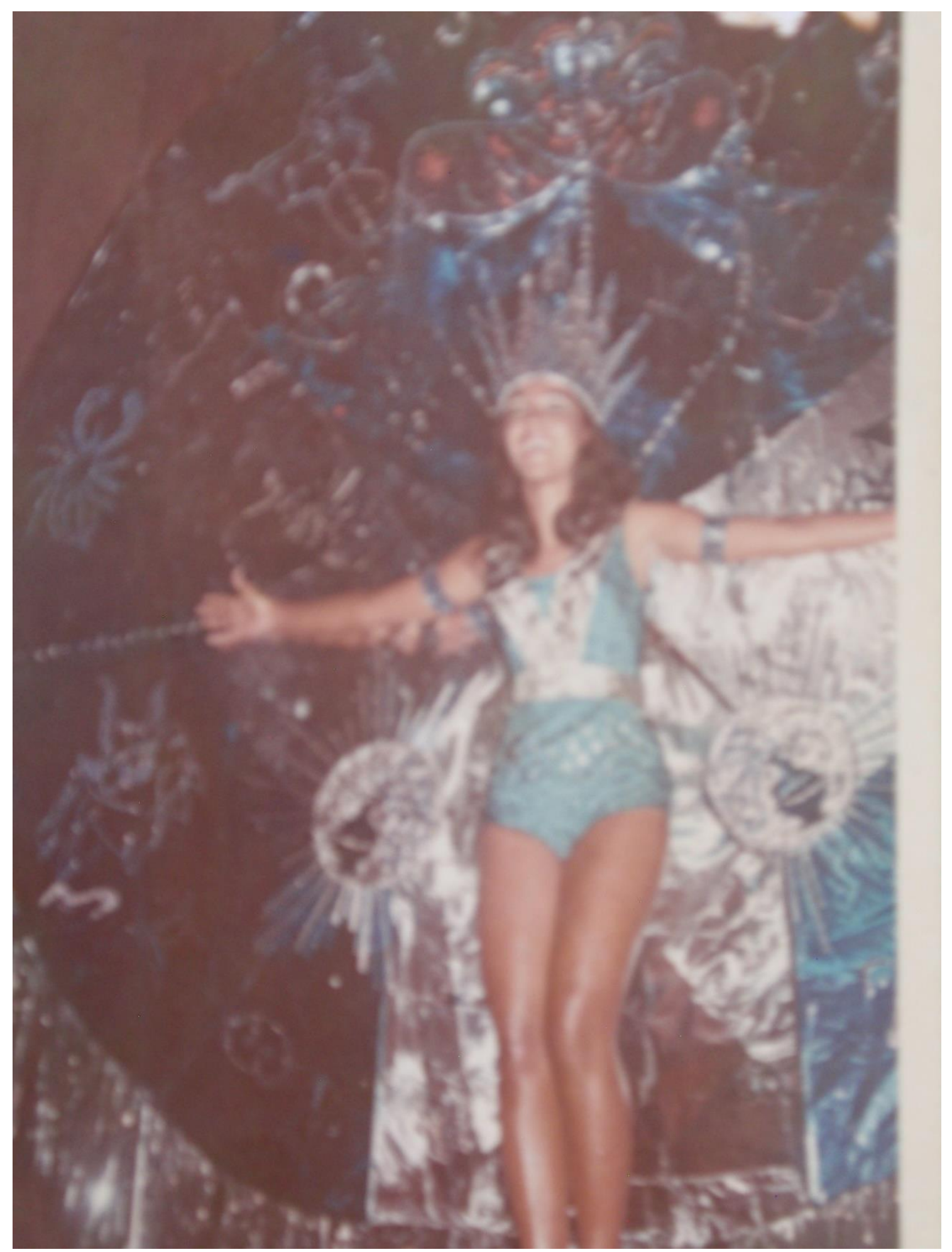

"She's ROYAL ... So ROYAL".

Cultural and Pedagogical Inquiry, Winter 2019, 11(1), pp. 105-136

ISSN 1916-3460 @ 2019 University of Alberta

http://ejournals.library.ualberta.ca/index.php/cpi/index 


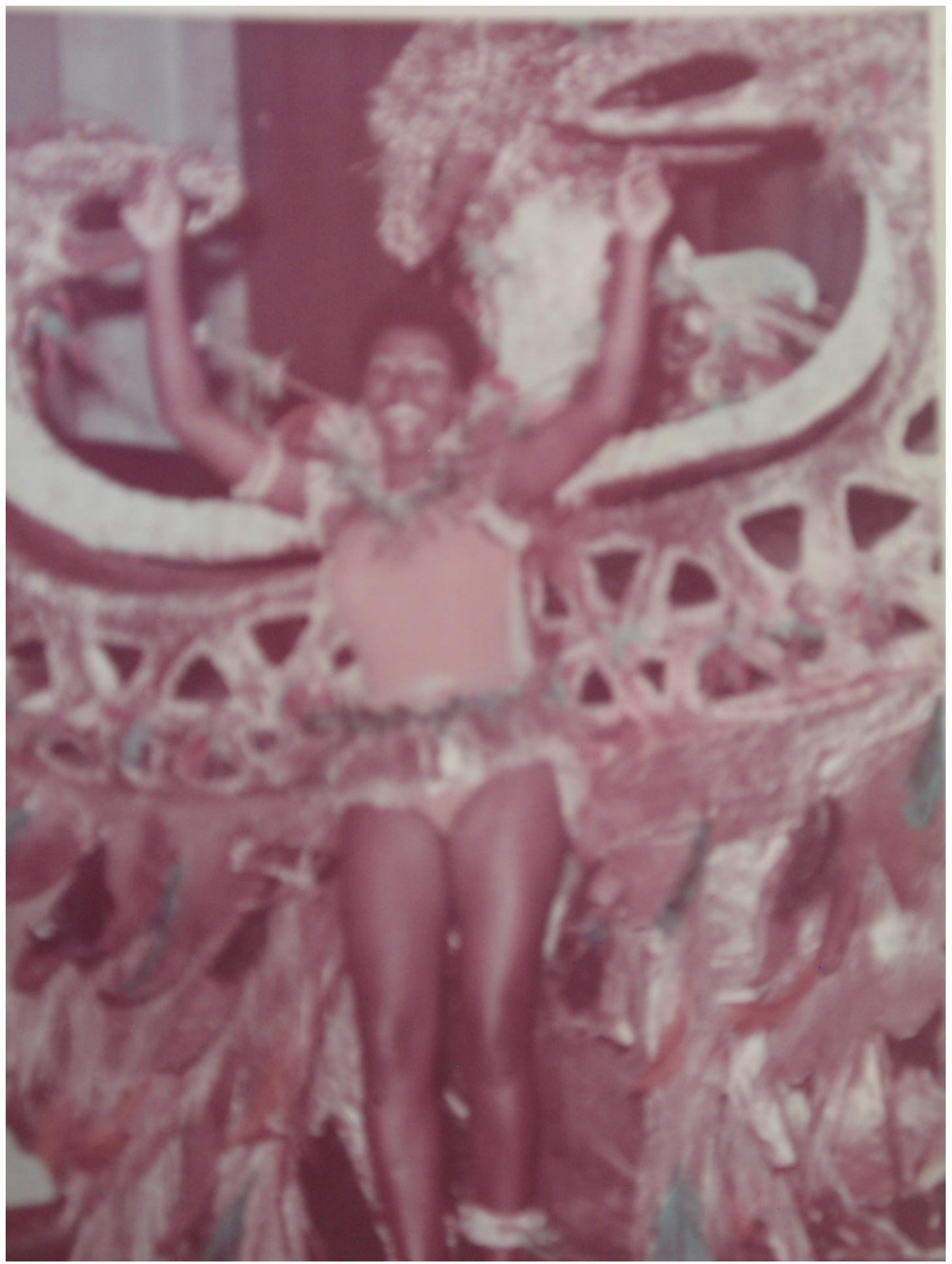

"She's ROYAL ... So ROYAL".

Cultural and Pedagogical Inquiry, Winter 2019, 11(1), pp. 105-136

ISSN 1916-3460 () 2019 University of Alberta

http://ejournals.library.ualberta.ca/index.php/cpi/index 


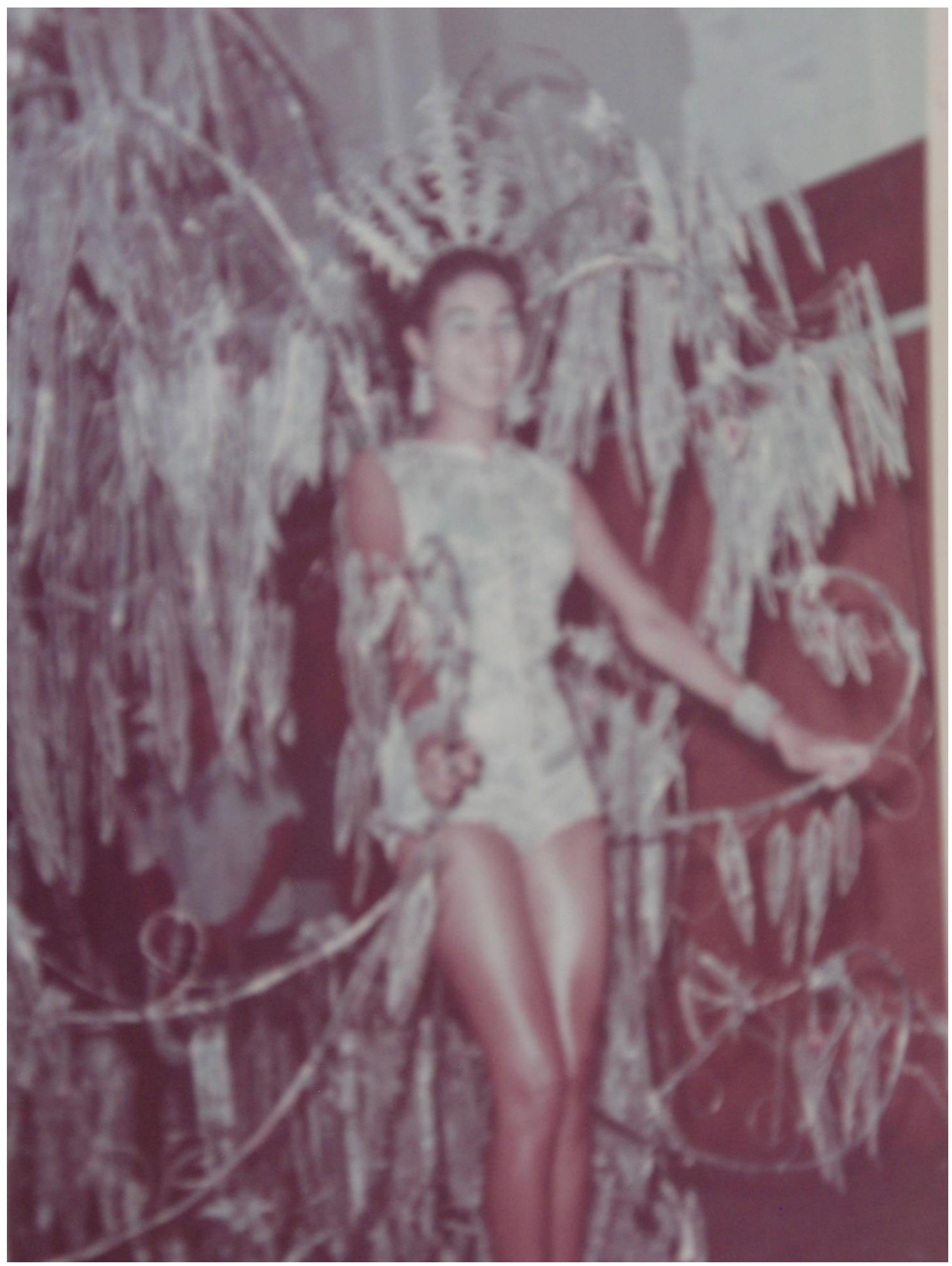

"She's ROYAL ... So ROYAL".

Cultural and Pedagogical Inquiry, Winter 2019, 11(1), pp. 105-136

ISSN 1916-3460 @ 2019 University of Alberta

http://ejournals.library.ualberta.ca/index.php/cpi/index 


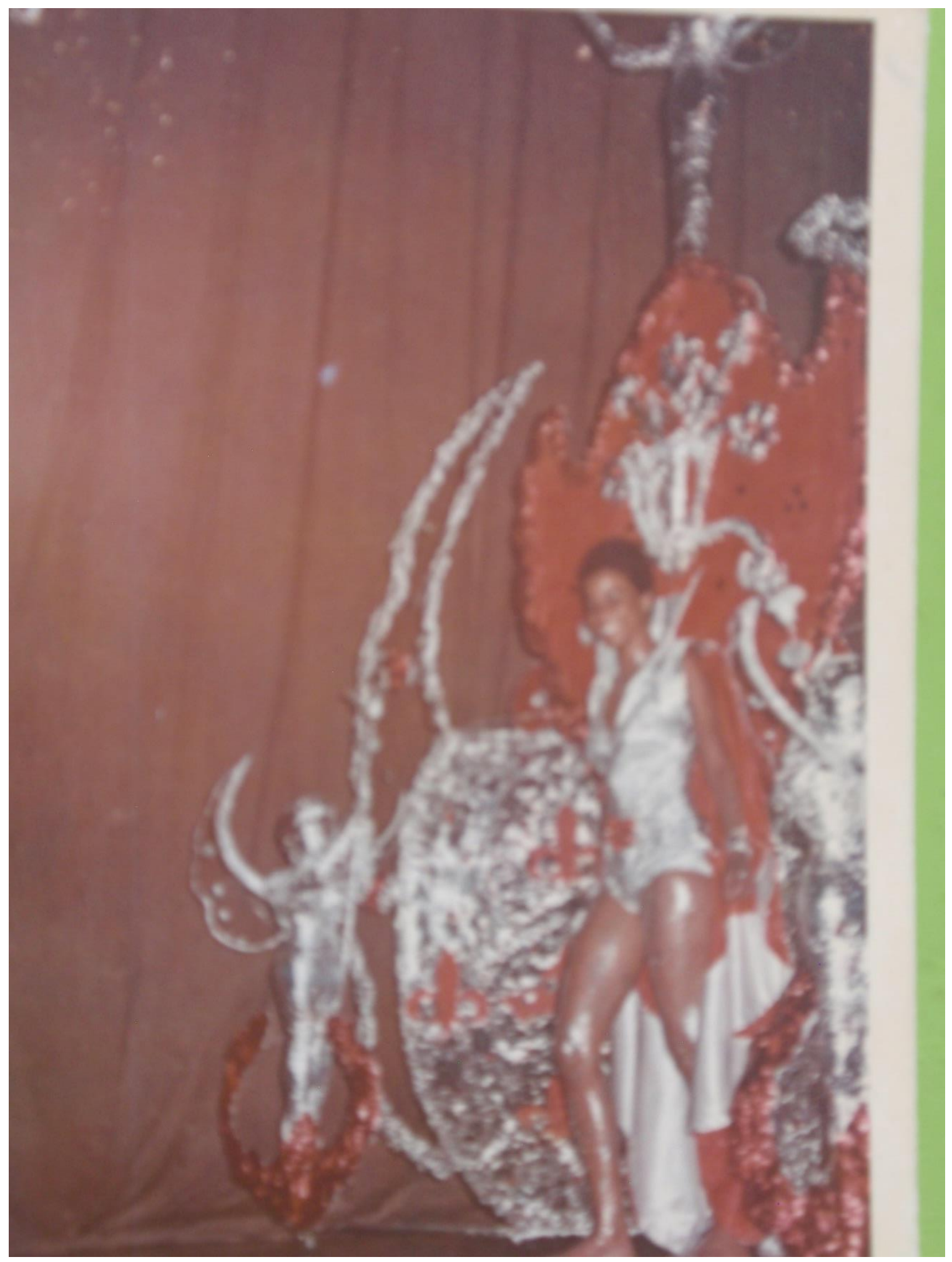

"She's ROYAL ... So ROYAL".

Cultural and Pedagogical Inquiry, Winter 2019, 11(1), pp. 105-136

ISSN 1916-3460 @ 2019 University of Alberta

http://ejournals.library.ualberta.ca/index.php/cpi/index 


\section{Series 3: Memories of Irvine Hall}

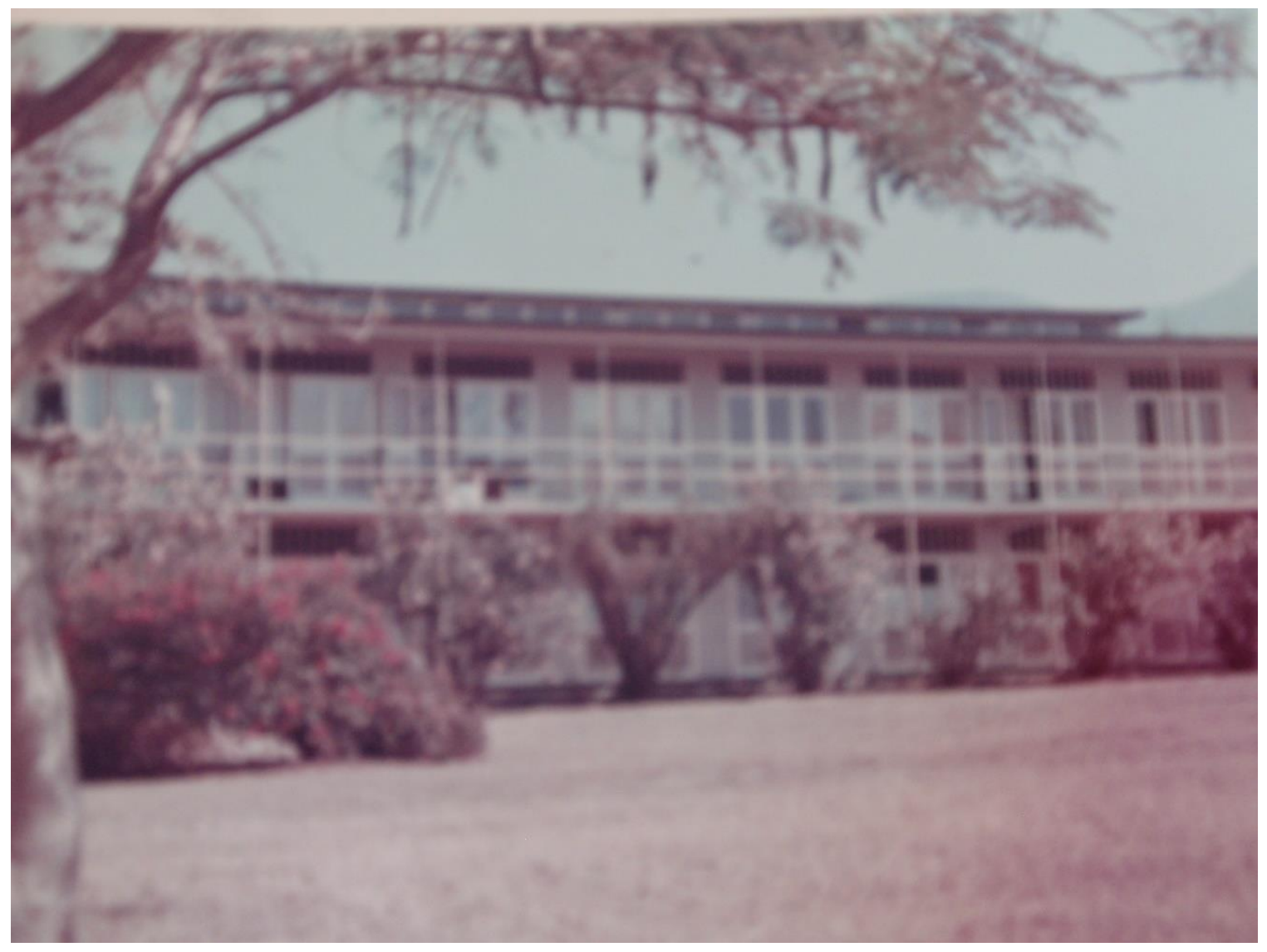

A home away from home.

Cultural and Pedagogical Inquiry, Winter 2019, 11(1), pp. 105-136

ISSN 1916-3460 @ 2019 University of Alberta

http://ejournals.library.ualberta.ca/index.php/cpi/index 


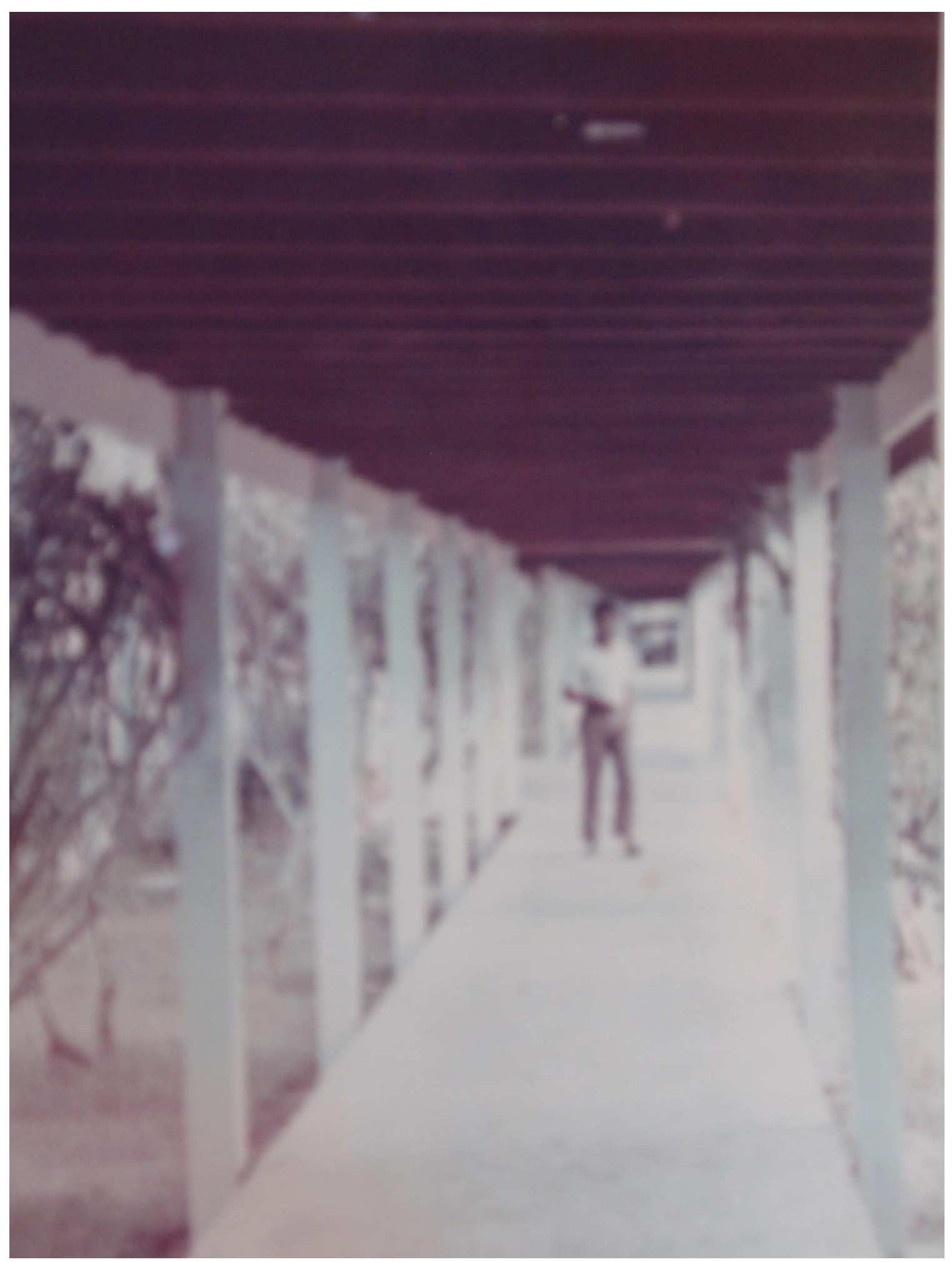

The Spine: where we once limed and laughed.

Cultural and Pedagogical Inquiry, Winter 2019, 11(1), pp. 105-136

ISSN 1916-3460 @ 2019 University of Alberta

http://ejournals.library.ualberta.ca/index.php/cpi/index 


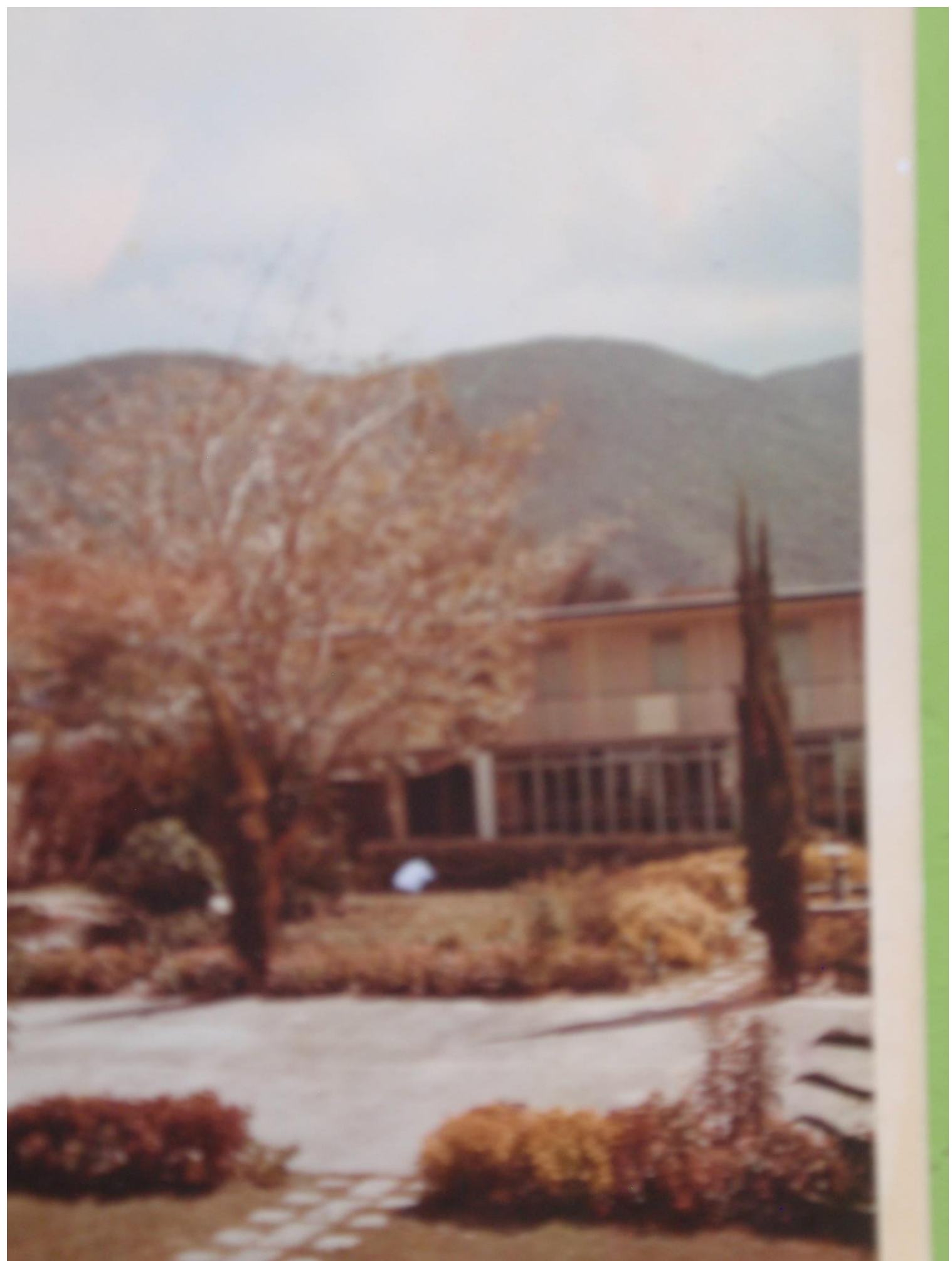

Home away from home.

Cultural and Pedagogical Inquiry, Winter 2019, 11(1), pp. 105-136

ISSN 1916-3460 @ 2019 University of Alberta

http://ejournals.library.ualberta.ca/index.php/cpi/index 


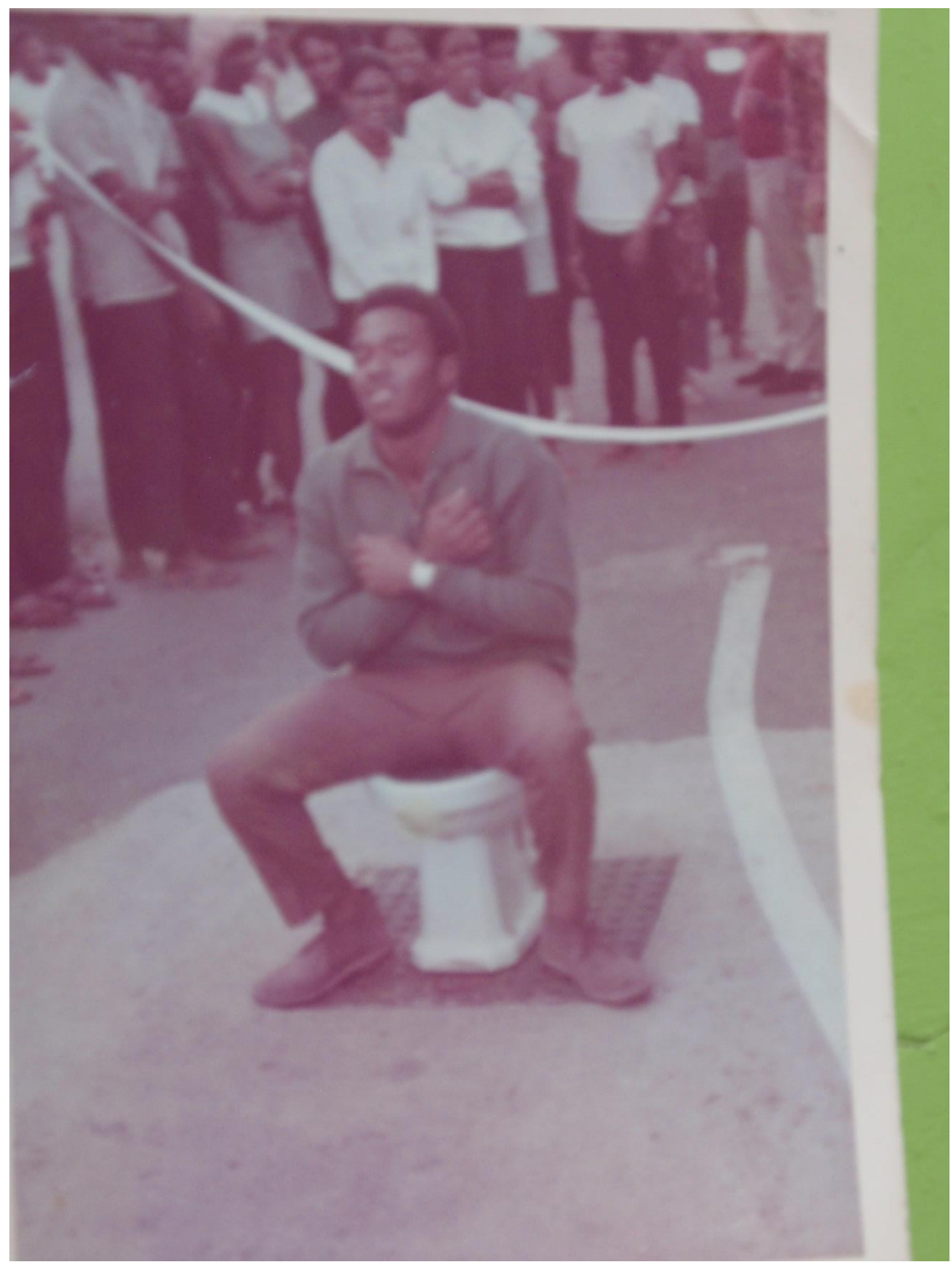

Initiation rites.

Cultural and Pedagogical Inquiry, Winter 2019, 11(1), pp. 105-136

ISSN 1916-3460 @ 2019 University of Alberta

http://ejournals.library.ualberta.ca/index.php/cpi/index 


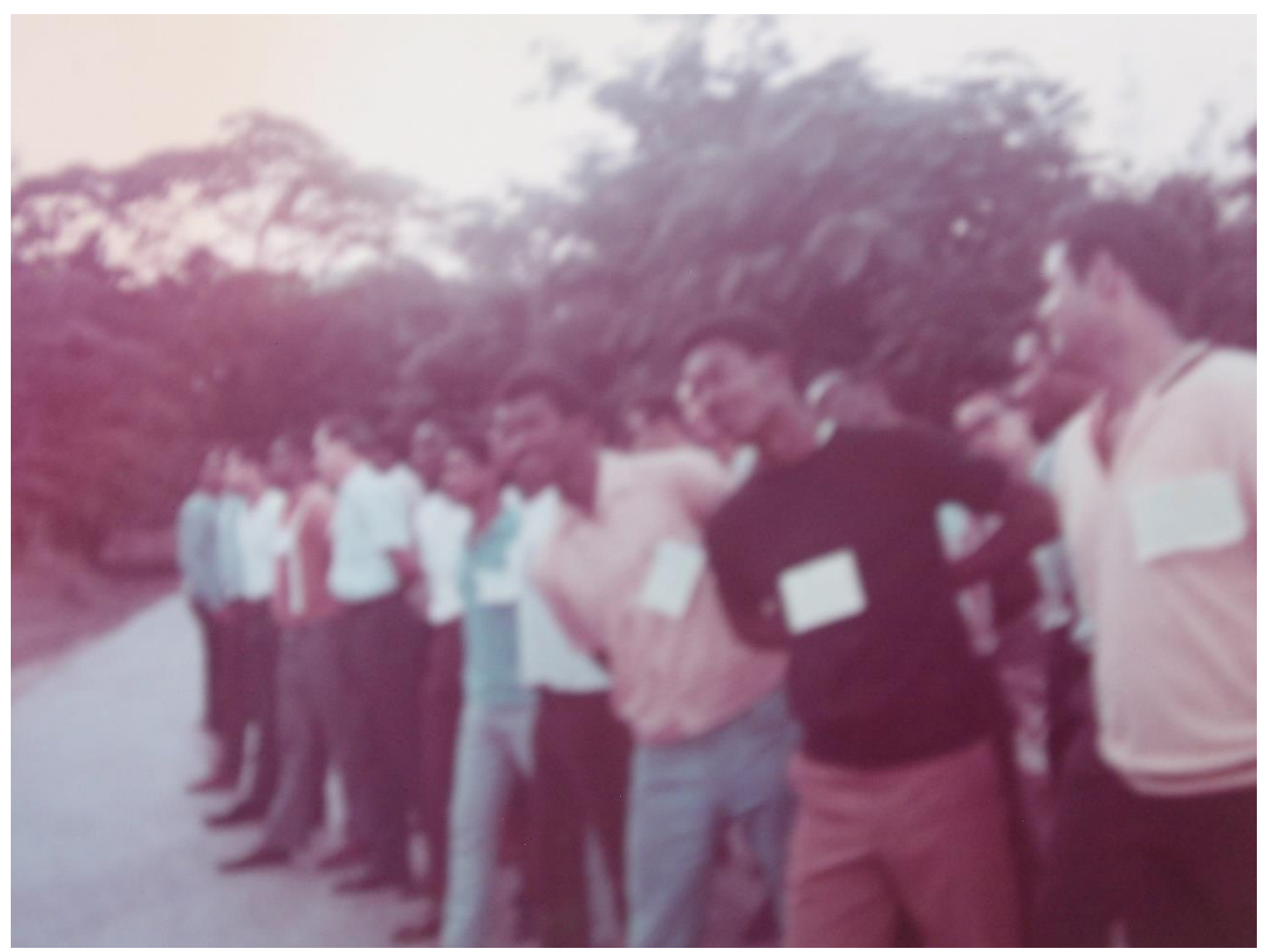

Initiation rites.

Cultural and Pedagogical Inquiry, Winter 2019, 11(1), pp. 105-136

ISSN 1916-3460 @ 2019 University of Alberta

http://ejournals.library.ualberta.ca/index.php/cpi/index 
Series 4: Participating in important campus events

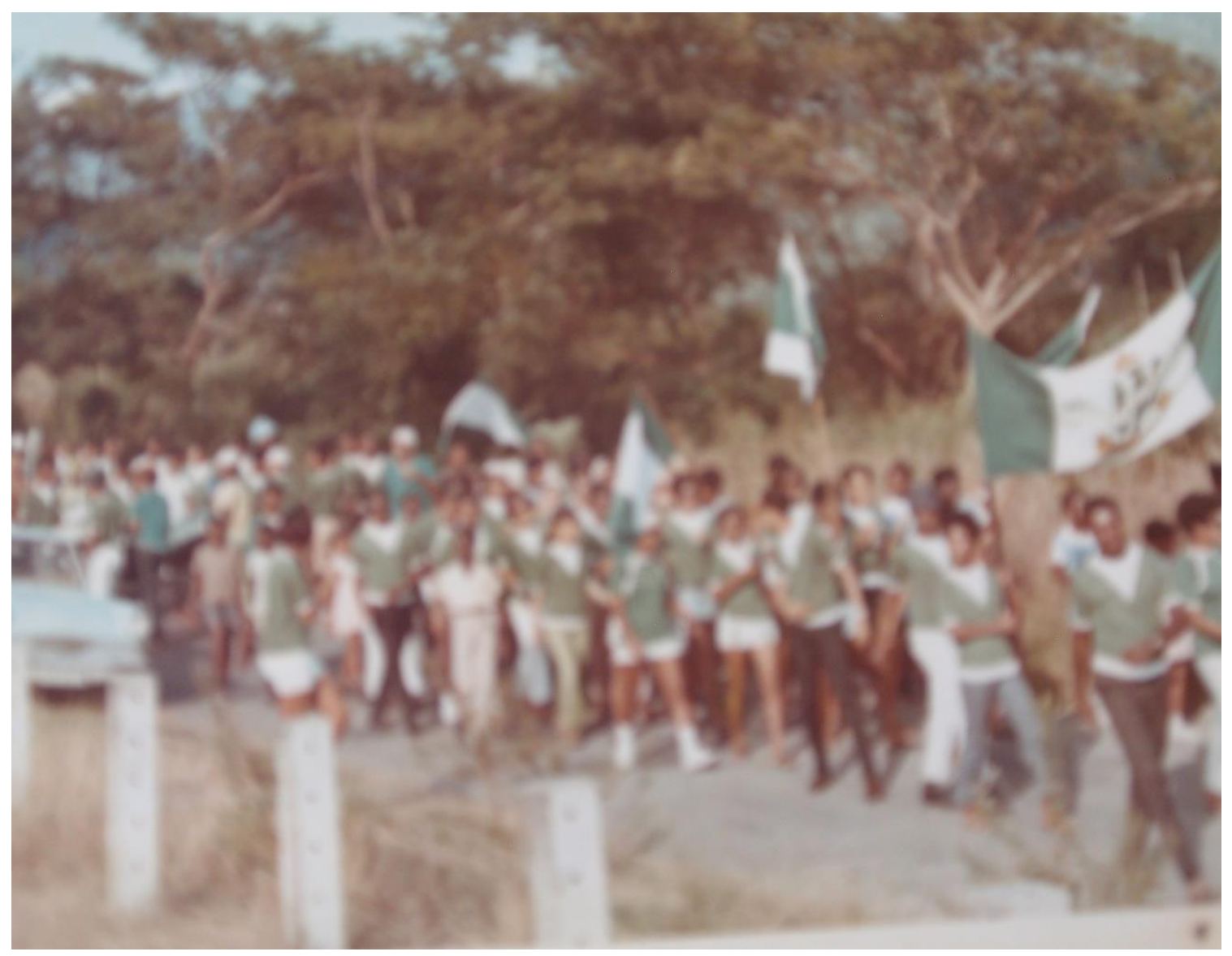

Some Irvinites, dressed in hall colours, singing and dancing to Irvine Hall's steel band (on the way to the football field).

Cultural and Pedagogical Inquiry, Winter 2019, 11(1), pp. 105-136

ISSN 1916-3460 () 2019 University of Alberta

http://ejournals.library.ualberta.ca/index.php/cpi/index 


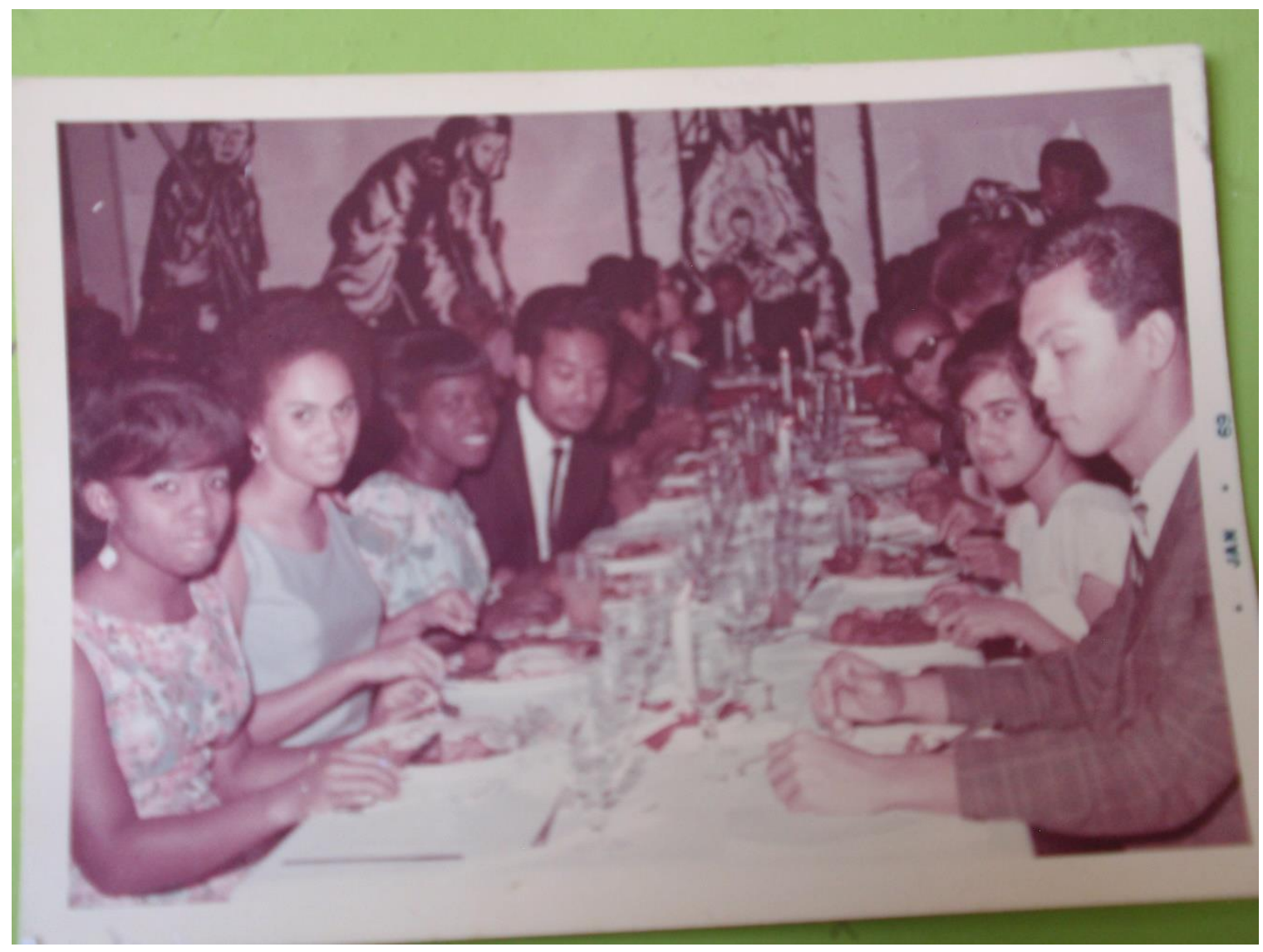

Enjoying Christmas Dinner, 1969.

Cultural and Pedagogical Inquiry, Winter 2019, 11(1), pp. 105-136 


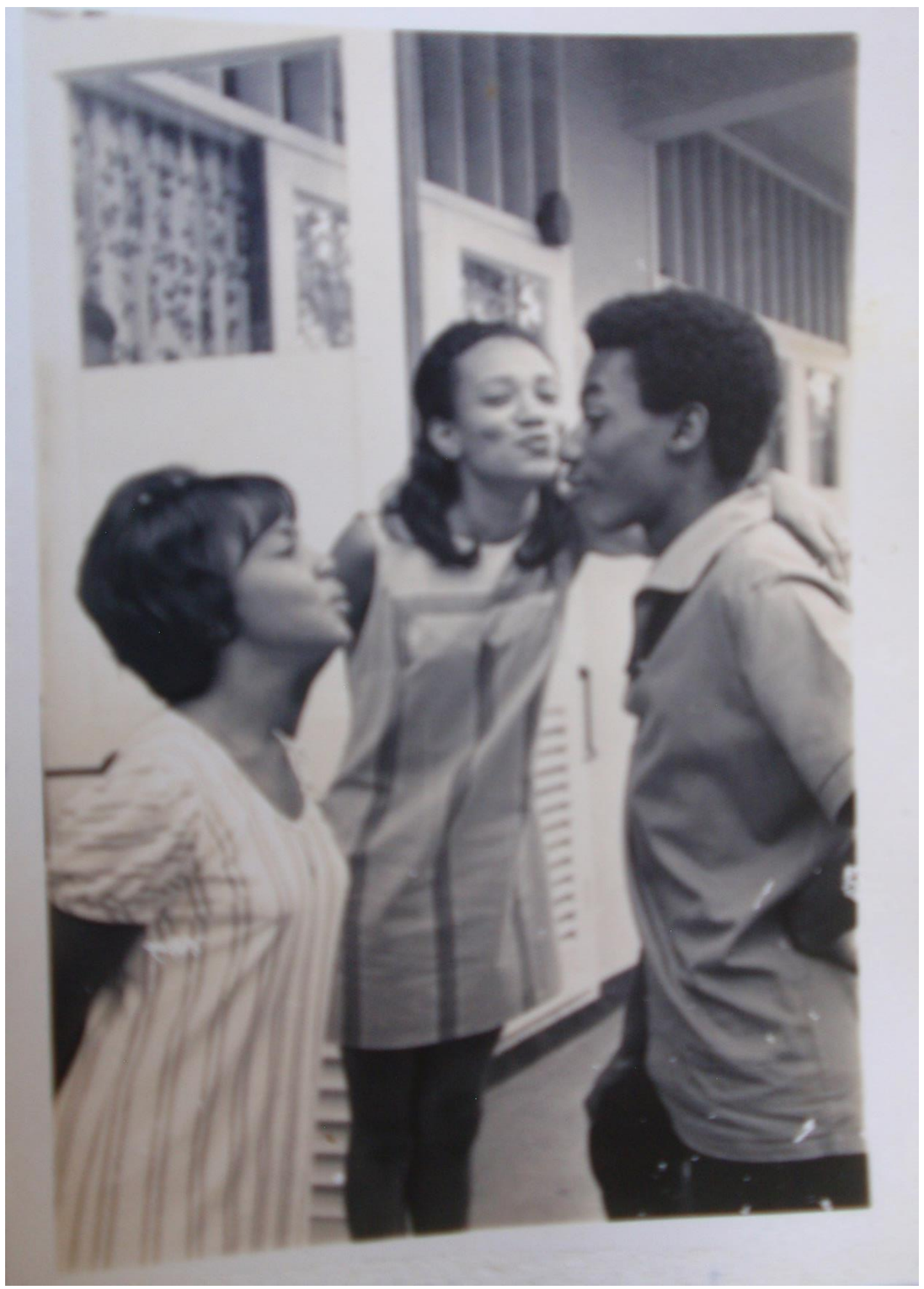

Too sweet for words.

Cultural and Pedagogical Inquiry, Winter 2019, 11(1), pp. 105-136

ISSN 1916-3460 () 2019 University of Alberta

http://ejournals.library.ualberta.ca/index.php/cpi/index 


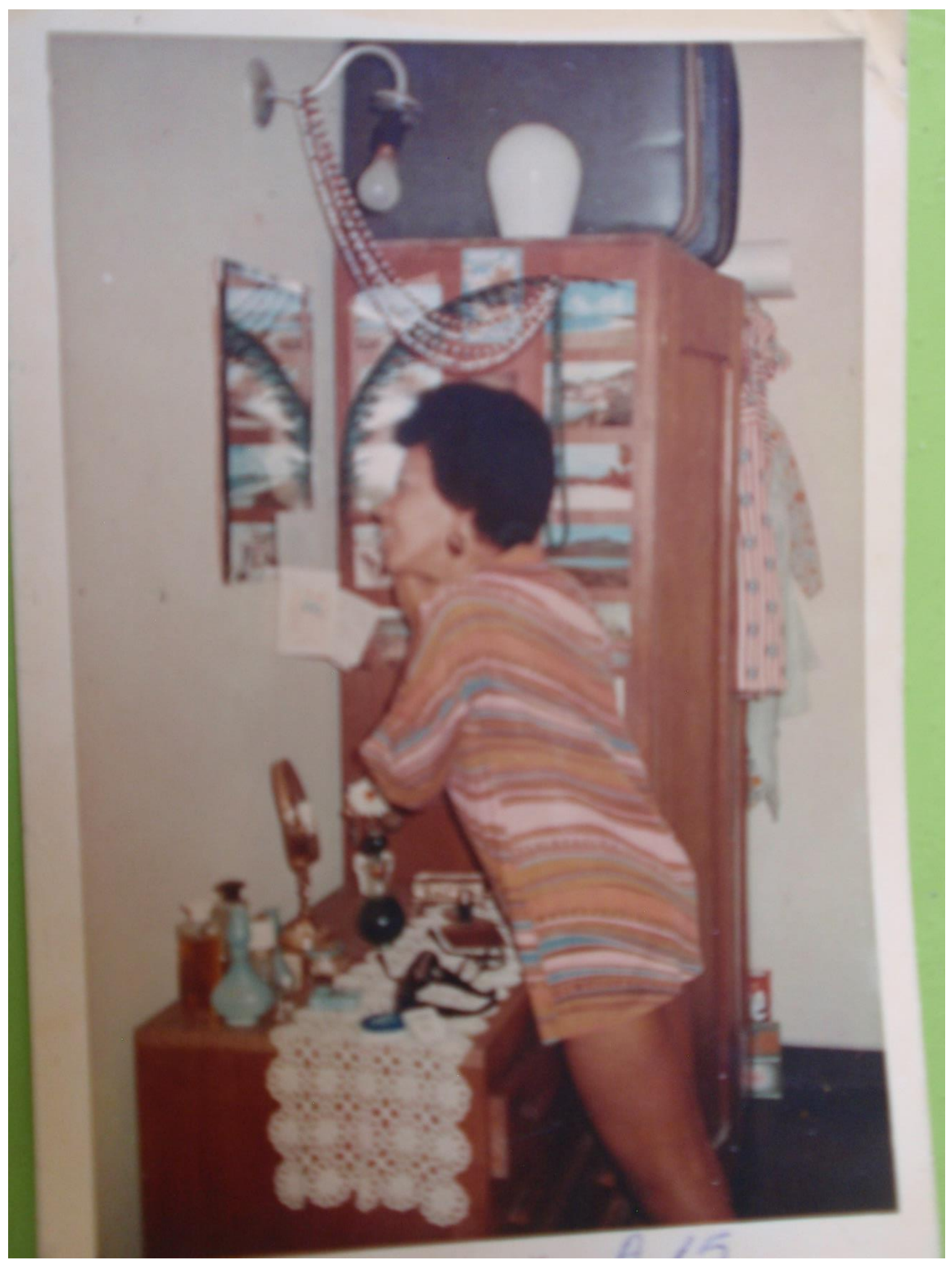

Too sweet for words.

Cultural and Pedagogical Inquiry, Winter 2019, 11(1), pp. 105-136

ISSN 1916-3460 () 2019 University of Alberta

http://ejournals.library.ualberta.ca/index.php/cpi/index 


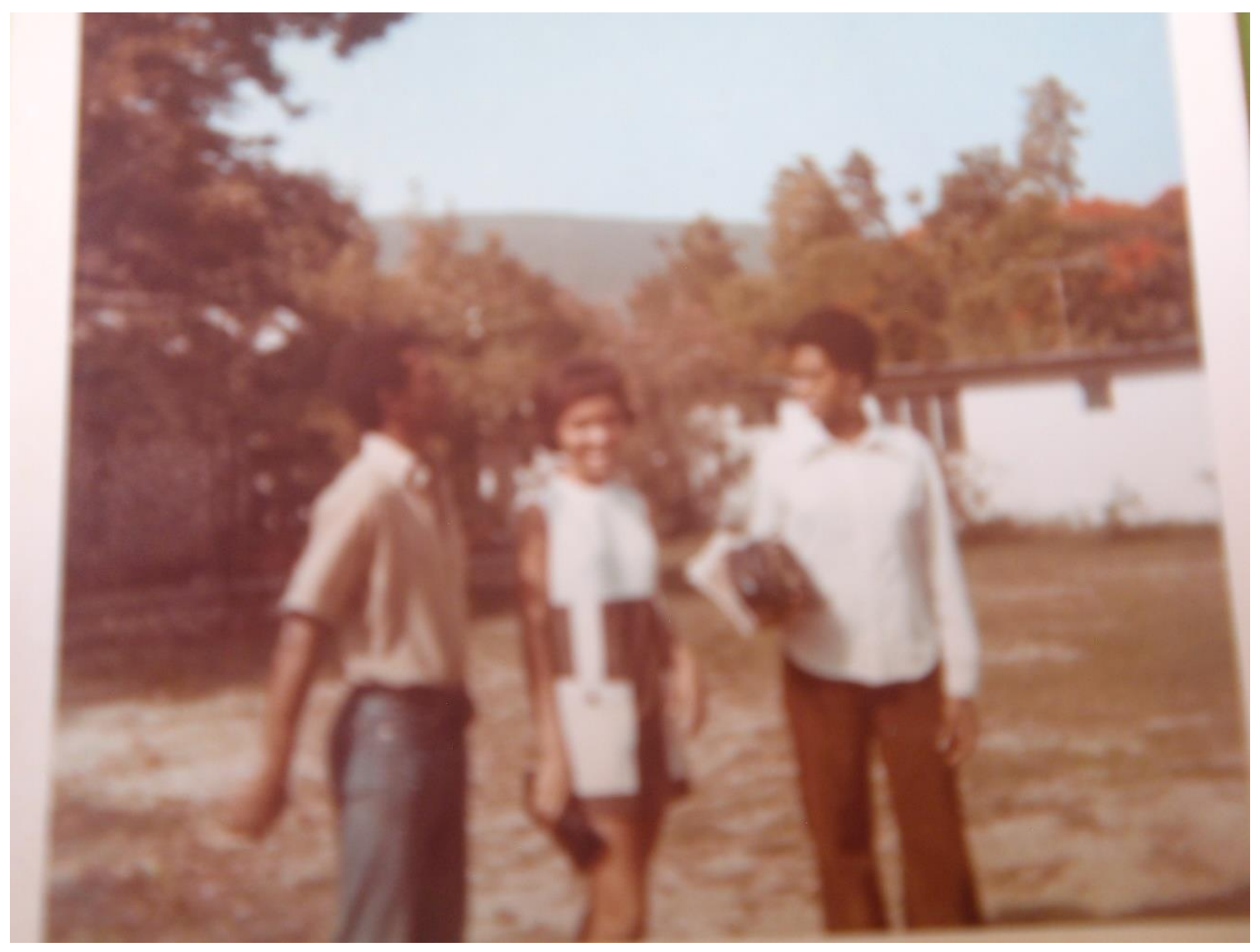

Still too sweet for words.

Cultural and Pedagogical Inquiry, Winter 2019, 11(1), pp. 105-136 


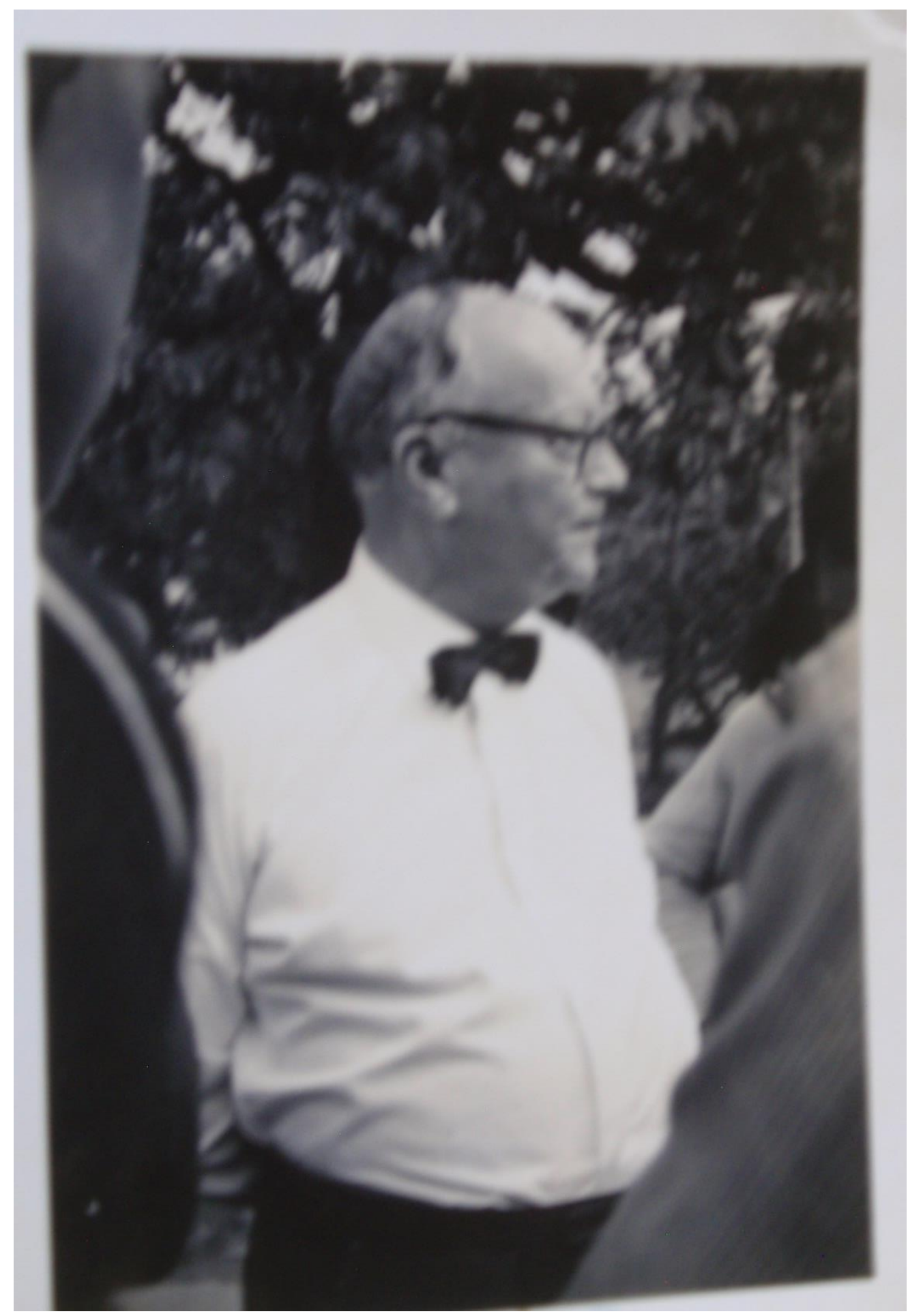

The Hon. Sir Philip Sherlock (KBE, OM, OCC).

"Under his brilliant leadership, the UWI grew in importance and prestige, and stands today, as his lasting monument" (Calabar Old Boys Association webpage, Sir Philip Sherlock).

Email: gillian.gleanwalker@gmail.com

Cultural and Pedagogical Inquiry, Winter 2019, 11(1), pp. 105-136

ISSN 1916-3460 @ 2019 University of Alberta

http://ejournals.library.ualberta.ca/index.php/cpi/index 
While at the St. Augustine campus... in the late 1960s

Selected photos from Terry/Teresa Subero, nee Lee's Archives

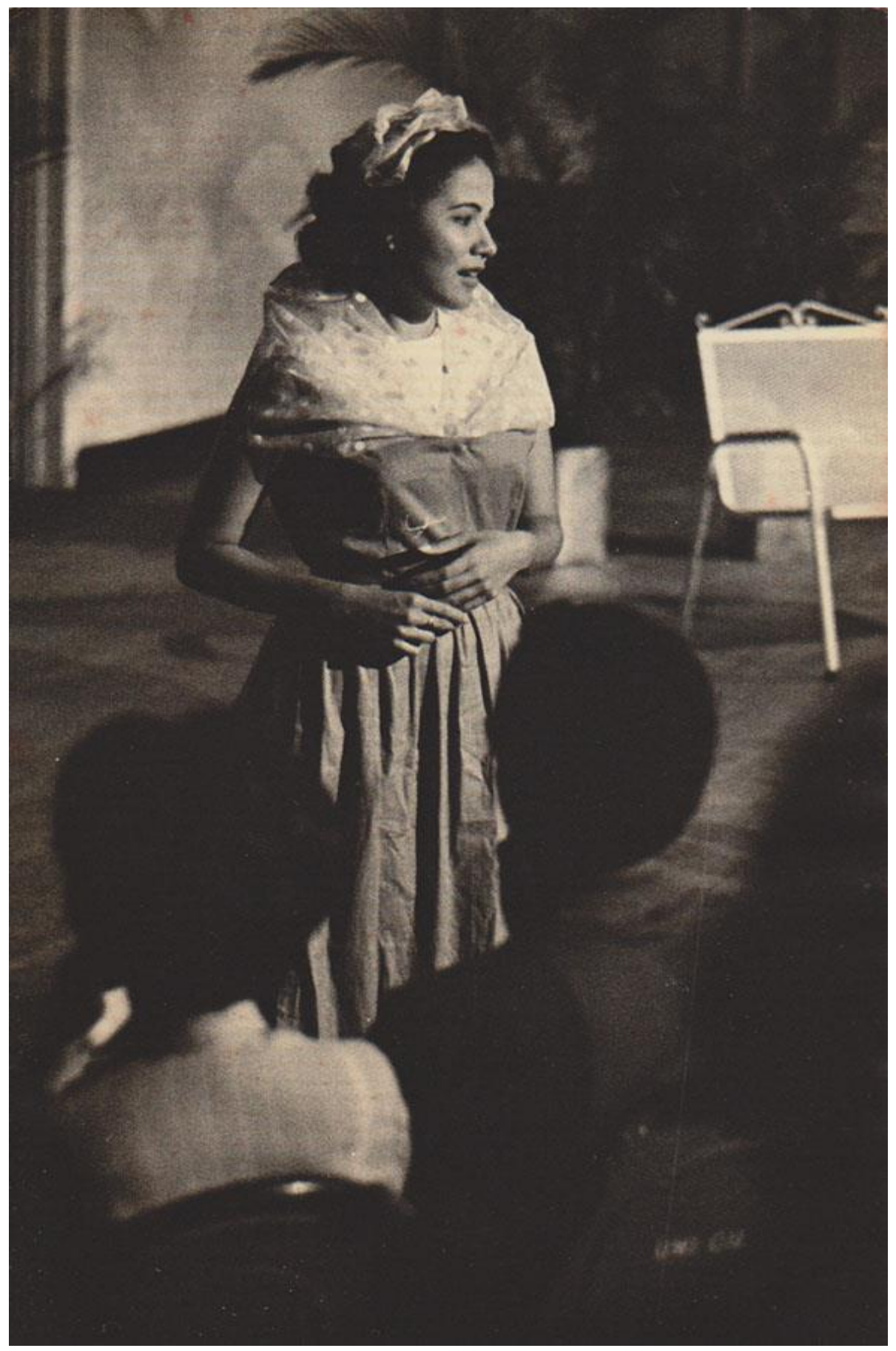

Teresa Lee, playing Sylvia, in Le Jeu de L'Amour et du Hasard by Marivaux. The play was staged in the old Guild Hall, St. Augustine Campus (1968-69).

Cultural and Pedagogical Inquiry, Winter 2019, 11(1), pp. 105-136 ISSN 1916-3460 () 2019 University of Alberta http://ejournals.library.ualberta.ca/index.php/cpi/index 


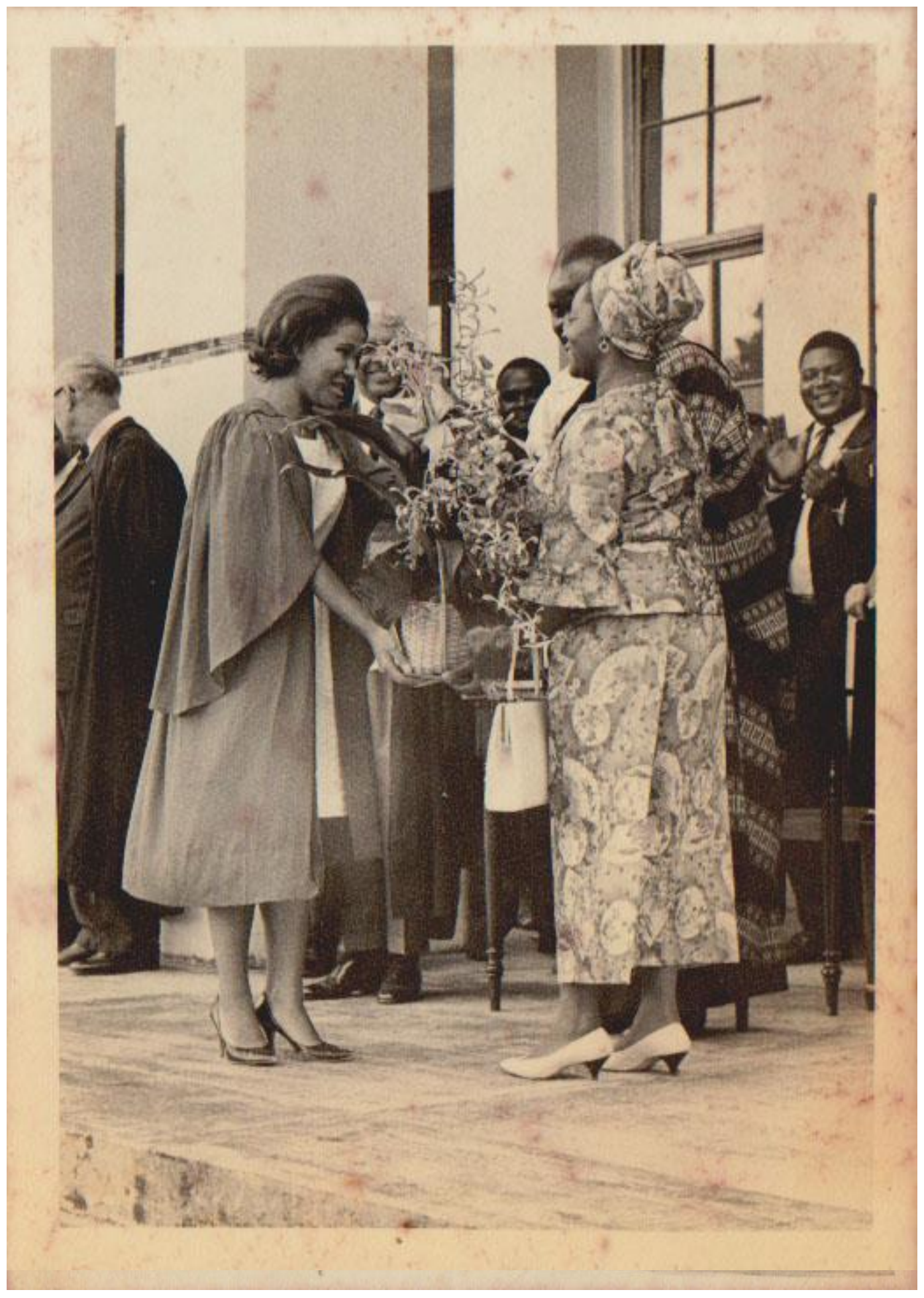

Teresa Lee, Freshette Queen (1966-67), presenting the wife of President Kenneth Kaunda of Zambia, with a bouquet of flowers. Meeting the Kaunda's when they visited the St. Augustine Campus was a memorable experience for me.

Cultural and Pedagogical Inquiry, Winter 2019, 11(1), pp. 105-136 


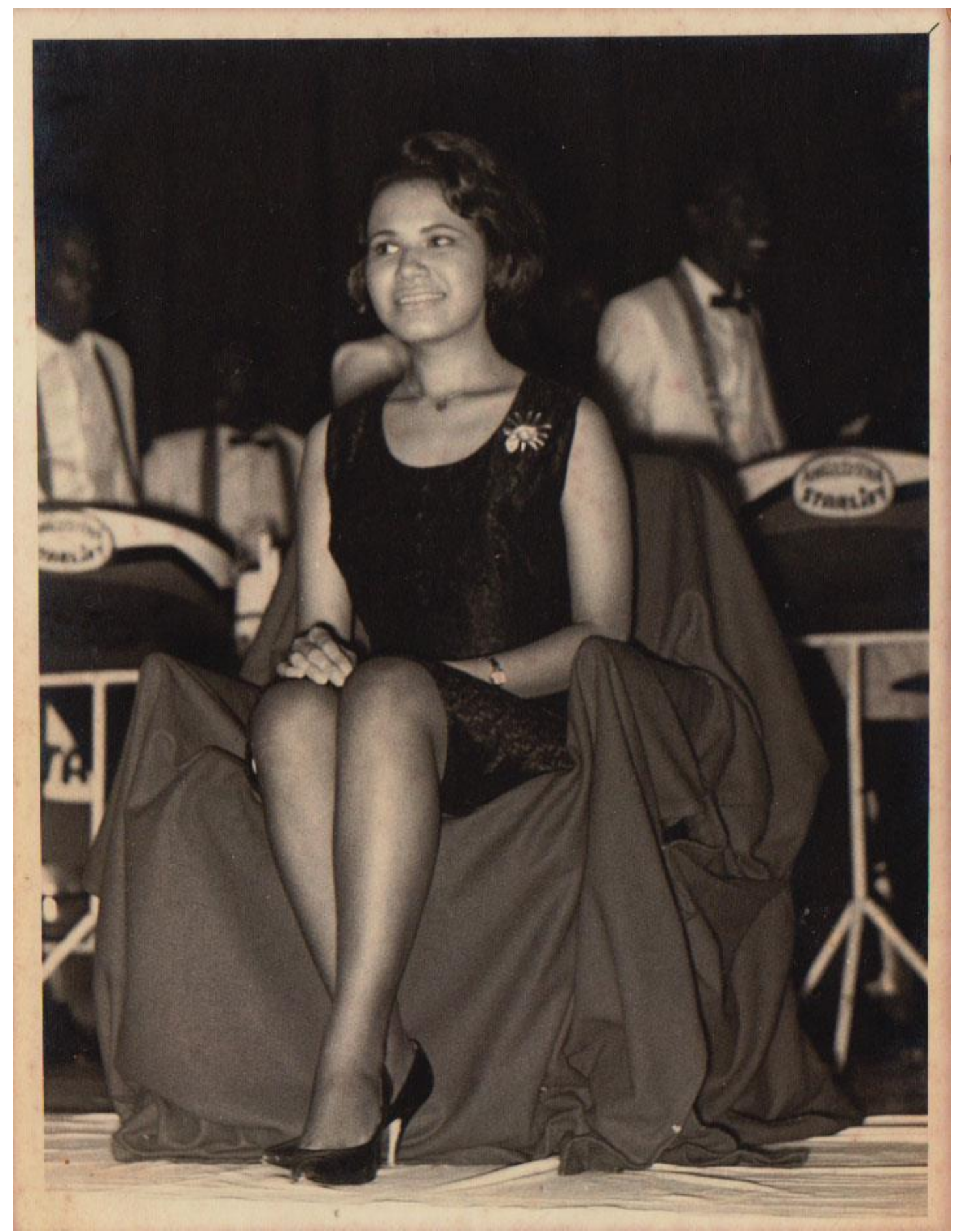

Teresa Lee being ‘crowned' Freshette Queen (1966-67).

Cultural and Pedagogical Inquiry, Winter 2019, 11(1), pp. 105-136 


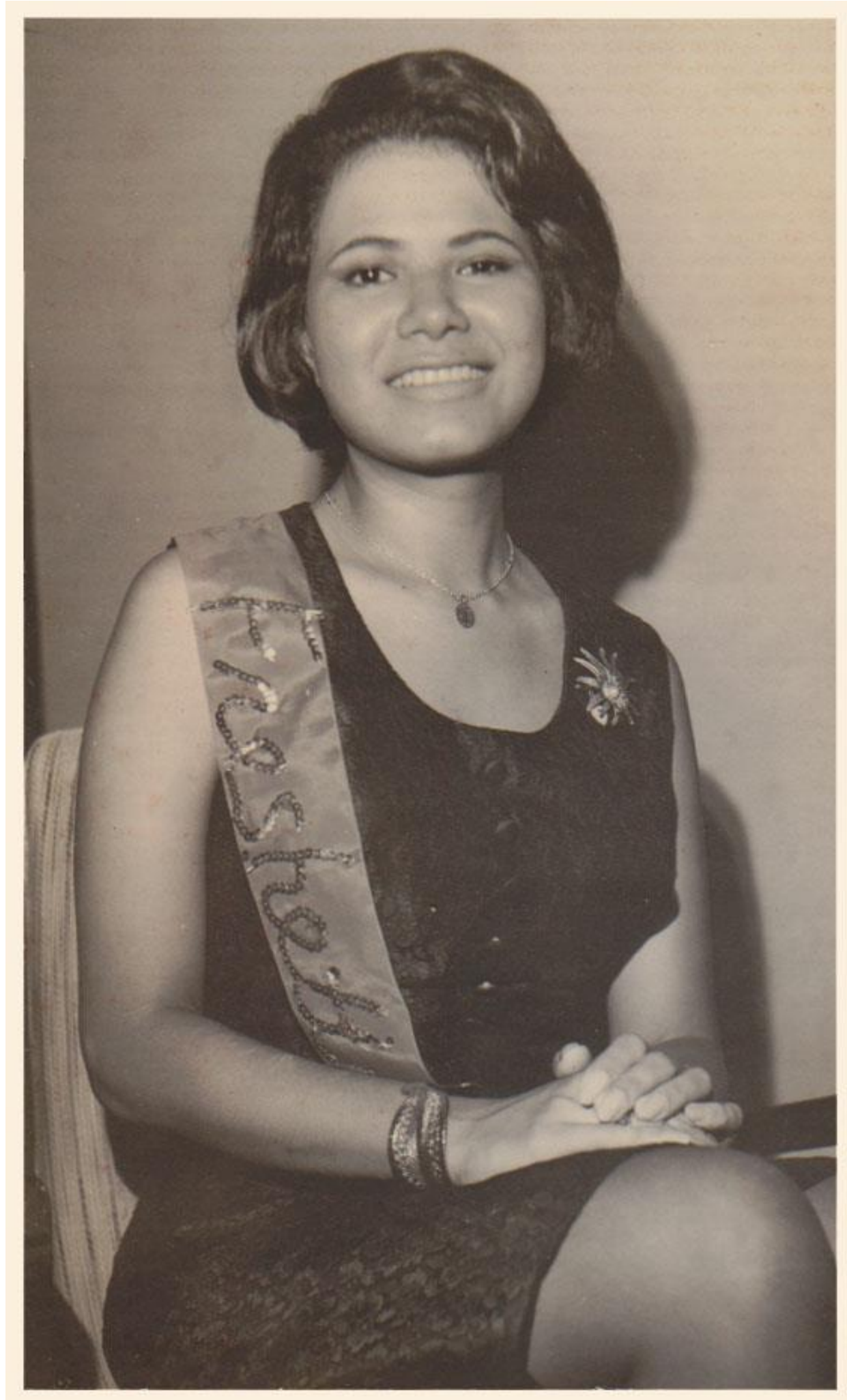

Teresa Lee being ‘crowned' Freshette Queen (1966-67).

Cultural and Pedagogical Inquiry, Winter 2019, 11(1), pp. 105-136

ISSN 1916-3460 @ 2019 University of Alberta

http://ejournals.library.ualberta.ca/index.php/cpi/index 


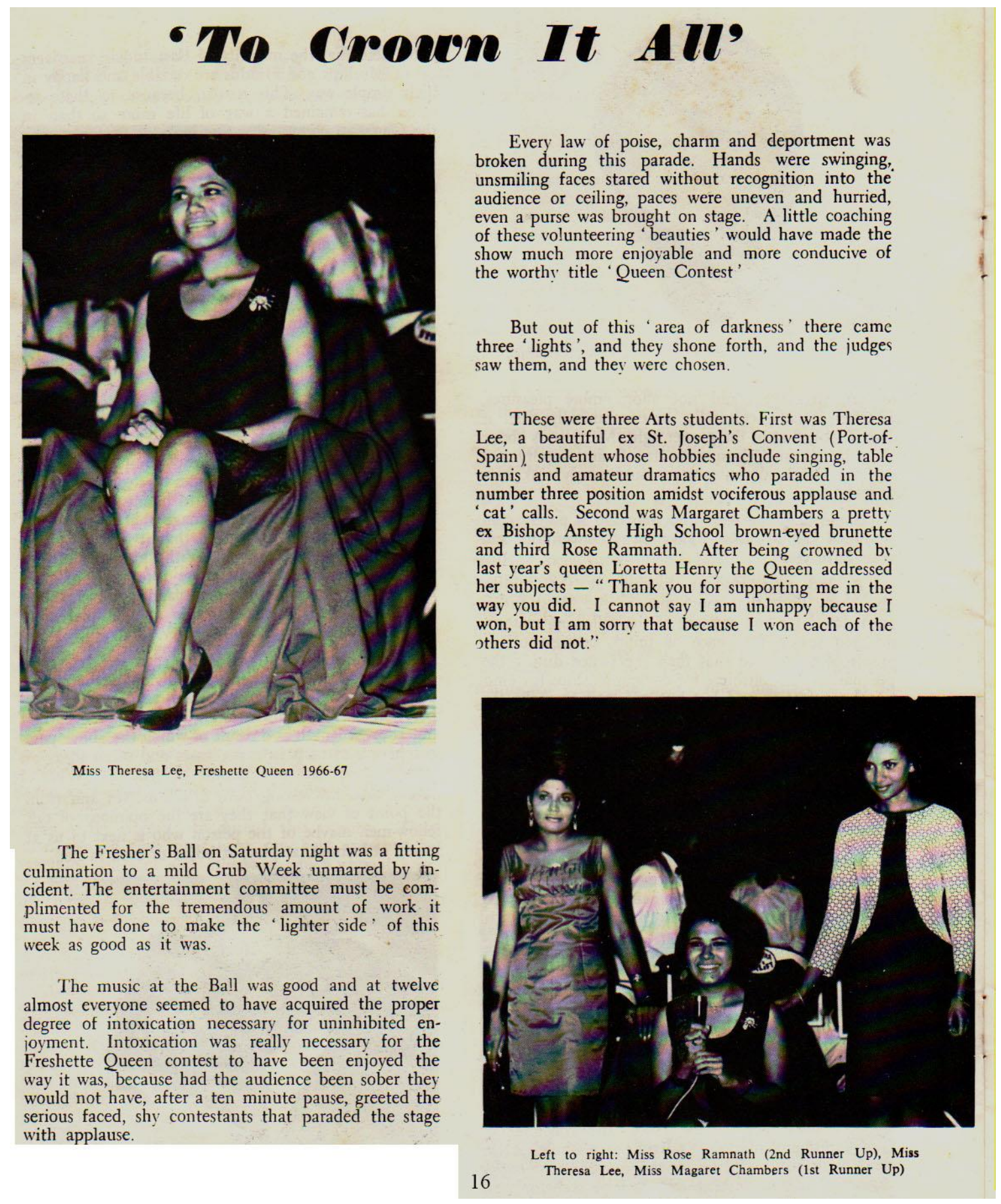

News item in the campus magazine, 'The Augustinian', Vol. 3, No. 1, Oct. 1966. 


\section{"Someone pushed the over-drive switch": UWI and Irvine Hall (late 1960s) \\ Ros M. Dopwell, nee Commissiong}

For 31 years, I have kept my memories of UWI, Mona, under tight lock and key. Then earlier this year, the lid began to come off the Pandora's Box. The memories began to escape. Little by little, they kept popping into my head and wouldn't go back... [to be] locked away, where they belonged.

First came the news, Dr. Indradit Ramsaran, was dead. He had died of complications of a heart problem.

Jo [Indradit Ramsaran's nickname] was truly 'a man for all seasons'...

- Learned advisor;

- Elder statesman;

- Confidante...;

- Mr. Authority on all topics... even, when we and he, himself, had not the simplest clue what he was expounding about...;

- One who frowned on leading others up a garden path, except in jest when he was 'The Clown Prince of the Practical Joke'.

Jo in my day was King of Irvine.

Now I hear that John Jones, 'the Crooner' is dead too, also of a heart attack.... John Jones of "Tomorrow's Children". To me he will be forever young... The man who sang, if not penned, certainly popularized, "Mr. Poor Man". Perhaps he too, [had] an overly enlarged heart!

...And people want me to come back to the Mona Campus?

- To a Students' Union which is a ghost town. Where there are no more fetes---all day--all night.

It isn't even safe to walk alone, day or night?

- To a campus where the Library and "book-beating", have taken over from Thursday's, half-day holidays, and time for the getting to know each other [social activities]?

- Where Freshman's week, has had to be so carefully policed that now, it is almost of no significance? Where it is as good as banned. And "freshettes" are no longer stopped and asked for their names. Or questioned: "What discipline do you wish to submit supplication to?" 
- Where the desert spoons are no longer flattened; made almost useless, due to ritual 'banging' [on the dining room tables, to express approval or disapproval]?

- Where our UWI gowns, at dinner (undergraduates wore red and graduates blue) are now non-existent. See us scurrying, to get to formal dinners on time.

Gowns wrapped around us; hiding all manner of 'undress'; including girls wearing shorts rather than, the formal prescribed, puritanical white dresses?

Now, No more formal dinners.

- Where pranks used to be for the sheer fun, and not meant to hurt, or be cruel. If so, they were censored by the 'Jo' Ramsarans and 'Atom' Persauds, amongst us. The older wiser heads.

- Where laughter was oft the indulged medication. Ringing out day and night.

- Where we were one big happy family. Almost, all of the time.

- Where hearts were broken (so badly, we thought we'd die), and healed almost once per week and twice on Sundays. But we usually got over the heartache, rather quickly. We realised that having one's heart broken was merely, a painful but integral part of growing up.... preparing us for the real world, waiting for us out there.

- Where Campus was the real, fairy tale, world. So real, that it was highly unreal. It was a vital preparation for the falseness of the real world which we were being prepared to live in.

This was not what university life was supposed to be about.

Hold back the aqueduct.

Let us sneak into the anatomy lab and scare ourselves out of our wits.

Let us climb over the fence into the pool and play water polo, by moonlight... boys vs girls. It was mostly, nice and innocent. Going to the pool, after a trip to Regal Cinema and to Monties Drive-in.

Though against the rules, which were made to be broken, such activities were not the ones which brought major tragedies:

- Promising sporting careers, cut short by injury or laziness, or lack of effort or stupidity (like drug abuse... alcohol is a drug).

- Flunking exams and dropping out, is as sad as, it is supposed to be.

Cultural and Pedagogical Inquiry, Winter 2019, 11(1), pp. 105-136

ISSN 1916-3460 @ 2019 University of Alberta

http://ejournals.library.ualberta.ca/index.php/cpi/index 
The above I can take.

The above are healthy.

The grim reaper is not supposed to invade our lives, as it did. Not so early. Not so often.

University life is supposed to be a real fairy tale; a taste of the real world. It is supposed to prepare one for the real world; for larger than life experience. But for those of us who attended the UWI, Mona Campus, in the late 1960s, someone pushed the 'over-drive switch'. Many of us got too large a dose of the real world. I for one DID!

(Extract from Ros Dopwell's letter to Gillian Glean Walker, Tuesday, October 24, 2000. Written in Grenada). 


\section{Carol Campbell}

Title:

Date:

Dimensions:

Mixed Media:

Exhibition Record:
"She Used To Be a Butterfly"

2005

Varied: 45 x $45 \mathrm{~cm}$; (Eye brooch 6 × 4 x $1 \mathrm{~cm}$ )

Paper collage, Plaster cast, Sterling silver, 24K gold, Labradorite, Cubic zirconia, Butterfly wings

2005 - "Let's Face it" Revolution Gallery, Kingston, Jamaica

2008 - Diasporavibe Gallery, International Cultural Exchange, St. Maarten

\section{Artist Statement}

Having observed, very closely and carefully, the mental retreat evidenced with the onslaught of Alzheimer's Disease, I was moved to create a piece that addressed this issue from the patient's perspective. Who can fully understand the debilitating confusion, the loss of communication, where the words can no longer find expressive exit through the mouth, where the eyes as windows to the soul, have the shades drawn and shuttered, where the only hope exists in the imagination, in flights of fancy (or fantasy) which is beyond reach, and incomprehensible to the onlooker?

But I know. In the depths of my soul, I remember. Don't judge me or label me because you do not understand me. If I smile, smile with me. If I cry, comfort me. The butterfly still lives, and the transformation continues.

Email: revolutiongallery.jm@gmail.com 


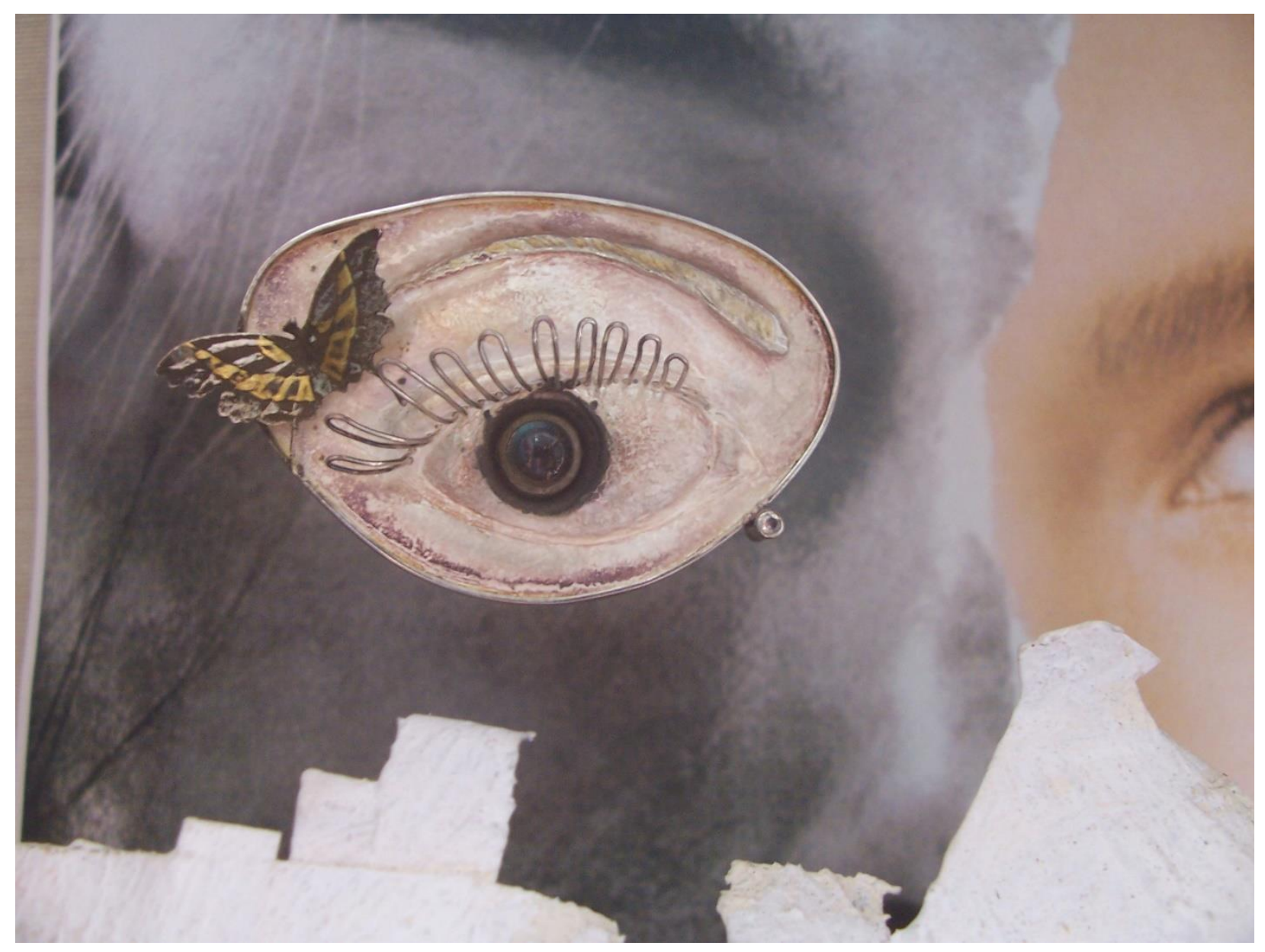

Cultural and Pedagogical Inquiry, Winter 2019, 11(1), pp. 105-136

ISSN 1916-3460 () 2019 University of Alberta

http://ejournals.library.ualberta.ca/index.php/cpi/index 


\section{OFTEN BUTTERFLIES (YELLOW) SWARM ON THE LIGNUM VITAE TREE \\ Dorothy Robertson}

Butterflies clustering, awesome sight,

Clustering round the vitae tree,

Fierce heat breaking-

Light rays flashing-

Butterflies clustering, swarming, vibrating,

Exuberant, exotic,

Quivering, moving,

In tropic light.

Humanity, poor butterflies, cluster too,

Cluster on earth, the vitae tree,

Pathways filling-

Great roads rushing-

Cities growing, expanding, unheeding,

City lights gleaming,

Exuberant, exotic

Piercing the night.

(Aside: The lignum vitae trees, bear the national flowers of Jamaica). 


\section{WILL SUCCEED}

\section{Sandra Dixon}

How can I move on when people constantly hold me back?

They say I will amount to nothing

That my life is hopeless because of my parental heritage

They frequently laugh and jeer at me - saying my dreams will not come to a reality

Words of mockery echo in my ears

I recall all the painful gossips that robbed me of my innocence

Deprived me of my will to move forward

The world offers me no compensation for my hurts

No reconciliation for my emotional bruises

My life is threatened by the selfishness of others

They resent me for trying!

They criticize me for succeeding!

The weapon of tantalization has been used to suffocate me in my stride for dignity As if I haven't been hurt enough by continuous lies, betrayal, envy, and deceit

As if my character has not been tainted enough by emotional violence

I stand abreast my pride and aspire to redeem what I have lost

With a deep conviction and a stir of determination

The road ahead seems strenuous, lonely, and tiring

But I will prove them all wrong

I will defy them that molest me emotionally and violate me spiritually

With my growing success I will embarrass them!

With my biblical statutes I will destroy them!

No one will hinder my progress

God's hands are upon me

He will save me from my enemies

My dreams and my goals will be fulfilled

With or without hindrance I will succeed! 


\section{THE CHAIN ${ }^{1}$}

\section{Christine Craig}

I no longer care, keeping close my silence

has been a weight,

a lever pressing out my mind.

I want it told and said and printed down

the dry gullies,

circled through the muddy pools

outside my door.

I want it sung out high by thin-voiced elders,

front rowing murky churches.

I want it known by grey faces queuing under

greyer skies in countries waking

and sleeping with sleet and fog.

I want it known by hot faces pressed against

dust streaked windows of country buses.

And you must know this now

I, me, I am a free black woman.

My grandmothers and their mothers

knew this and kept their silence

to compost up their strength,

kept it hidden

and played the game of deference

And agreement and pliant will.

It must be known now how that silent legacy

nourished and infused such a line,

such a close linked chain

to hold us until we could speak

until we could speak out

loud enough to hear ourselves

loud enough to hear ourselves

and believe our own words.

(In Mordecai, 1987, p. 56).

\section{Endnote}

1. Permission to reprint Craig's poem granted by Pamela Mordecai and by Ms. Nakano, Mina Press Publishing, Sebastopol: California, January 2017.

\section{Reference}

Mordecai, P. (1987). From our Yard: Jamaican Poetry Since Independence. Kingston: Institute of Jamaica Publications Ltd.

Cultural and Pedagogical Inquiry, Winter 2019, 11(1), pp. 105-136

ISSN 1916-3460 () 2019 University of Alberta

http://ejournals.library.ualberta.ca/index.php/cpi/index 